shaped world history, for better or worse. Given its subject, the book has to provide insight into the ever-topical question of women in science. Women have not often won Nobel prizes. Of 566 laureates up to and including 1988, it looks as though only 19 have been women (although I am open to correction on this very properly in this feminist age the Nobel Foundation Directory does not include the sex of the winner). Furthermore, Marie Curie is the only woman ever to have won the prize for physics, and of the eight science prizes awarded to women, the Curies have won three. Only four people have won the Nobel prize more than once - Marie Curie, John Bardeen, Fred Sanger and Linus Pauling. Marie was the first woman to be awarded any Nobel prize and no woman other than a Curie had won the prize for science until Dorothy Hodgkin in 1964.

By contrast to art and literature, success in science presumably usually demands some sort of public position and command of resources. There is no doubt, as the book makes clear, that in the early part of the century women were scarcely tolerated in science. That there are precious few around today finds its roots in this. The problem did not exist simply in France, but also in Britain and Germany, where Max Planck said "If a woman has a special gift - which does not happen very often, I do not think it right to refuse her the chance to study..., but such a case must be regarded as an exception." And Planck was among the most progressive of his generation. Marie Curie's friend, Hertha Ayrton, was refused a fellowship of the Royal Society apparently because she was a married woman. But the trouble is that the Curies are too extreme to be a useful example. They test to destruction any possible sociological theory for the absence of women in science.

Anyone who turns winning the Nobel prize into a family business deserves a biography. The Curies were the family. This is the biography. I think it is rather good.

John Galloway is at the Cancer Research Campaign, 2 Cariton House Terrace, London SW1Y 5AR, UK.

\section{Not so sweet dreams}

\section{John Walter}

Poisons of the Past: Molds, Epidemics, and History. By Mary Kilbourne Matossian. Yale University Press: 1989. Pp.190. $£ 18, \$ 25$.

Bread of Dreams: Food and Fantasy in Early Modem Europe. By Piero Camporesi. (Translated by David Gentilcore.) Polity: 1989. Pp.212. £19.50, \$27.50.

THE past, we are told, exists only in the present. If so, then these books dealing with the historical impact of contaminated foods are timely reminders of the exchange between the concerns of the present and the past in the construction of history. Both deal with past societies, for which the invocation "give us this day our daily bread" had a special resonance, since the consumption of bread in large quantities was for most their daily diet. The authors of both these books argue that the tainted nature of this bread killed in appalling numbers and, more provocatively, that it left many in a quotidian world of narcosis and neurosis.

Demographers have become increasingly aware of the central importance of disease in understanding past demographic regimes. Matossian argues that they need to add an awareness of the significance of mycotoxicoses in explaining the behaviour and, she argues, beliefs of past societies. Central to her thesis is the prevalence of ergotism in past societies where rye provided the main foodstuff.

Ergotism in rye can be lethal. In Russian epidemics of the nineteenth century, mean mortality rates of those reported affected were just over 40 per cent. In addition, ergonavine can act as an abortifacient whereas other alkaloids suppress fertility or lactation. Moreover, by acting as immunosuppressants, these chemicals weaken the body's resistance to infectious disease. Matossian claims to find in these relatively recent discoveries answers to some of the conundrums that a population failed to grow after a plague, and renewed epidemics do not explain why, then try ergotism, she suggests. Similarly, ergotism (and fusarium moulds on poorly stored grain) helps to explain peaks in mortality and troughs in fertility in successive centuries. Matossian suggests a switch from rye to wheat, maize and potatoes as staples of people's diet to explain that final demographic conundrum - the take-off of western Europe's population into self-sustaining growth.

Arguing that there was a similar improvement in the mental health of Europe's population after 1750, Matossian goes on to claim a role for ergot poisoning in explaining what she believes to be past collective psychoses. Ergot, a source of lysergic acid diethylamide, may include natural alkaloids that act like LSD, creating hallucinatory and suggestible mental states, whereas other ergot alkaloids interfere with the activity of dopamine in the body, causing muscular spasm as well as delusions and hallucinations. The behaviour in the witch-craze of the sixteenth have previously puzzled demographers. If and seventeenth centuries, the "great fear" that mobilized peasant communities in the French Revolution or the religious revivalism in the United States in the 1740 s owes something, Matossian alleges, to ergotism.

This is a bold book with a stimulating thesis. Matossian's claims for the role of food poisoning will need to be incorporated into any satisfactory account of past demographic trends. Readers unfamiliar with existing work in this field should be warned, however, that the claim for the importance of ergotism is greatly helped by Matossian's tendency to dismiss too quickly existing alternative explanations and that, in the absence of hard evidence, the thesis rests on creative, but inferential, arguments that some, perhaps most, will find unsatisfactory. The argument also requires that rye was the main bread of the people, a claim that needs greater justification for England, at least. Matossian begins with good advice about the dangers of riding a hobby horse, but on occasion abandons caution. In particular, her final chapter, which seems to suggest that the key episodes in the European past (for example, the Reformation) might owe something to ergot poisoning, calls to mind the British MP Edwina Currie's disastrous courting of publicity by provocation.

Bread of Dreams covers similar territory, but from a slightly different perspective. Camporesi, a literary historian, examines the fears and fantasies Italians in pre-industrial times wove around food and famine. He uses essentially literary sources - but what sources! The writings of Baroque doctors and thinkers provide a point of entry into a world of repeated famines and persistent malnourishment where 'men of science' wrote tracts advocating an alarming range of food substitutes and believed that natural magic could convert poisonous herbs into the staff of life.

The reality, Camporesi argues, was very different. For him, Italy until at least the end of the eighteenth century was a society in which many of the people were the victims of hunger, producing hallucinations and tremors dementia. Poverty led to the baking of bread adulterated with substitutes such as poppy seed or darnel which induced narcosis, while a peasant pharmacopeia featuring such items as henbane or hemp fibre also induced a 'green deliria'. The literary nature of Camporesi's sources makes it difficult to assess how far what he describes was an historical reality, but Bread of Dreams is a remarkable and exciting recovery of an earlier cosmology elaborated around bread and body.

John Walter is in the Department of History, University of Essex, Wivenhoe Park, Colchester CO4 3SQ, UK. 